\title{
EU NO FACEBOOK: PERCEPÇÕES DE USUÁRIOS SOBRE IMAGENS PESSOAIS PARTILHADAS NA REDE
}

MYSELF ON FACEBOOK: USERS' PERCEPTIONS OF PERSONAL IMAGES SHARED ON THE NETWORK

\section{YO EN FACEBOOK: LAS PERCEPCIONES DE LOS USUARIOS SOBRE LAS IMÁGENES PERSONALES COMPARTIDAS EN LA RED}

\author{
Idilva Maria Pires Germano* \\ Jéssica da Souza Carneiro ${ }^{* *}$ \\ Livia Maria de Andrade Pontes ${ }^{* * *}$ \\ Pâmela Bezerra da Silva ${ }^{* * *}$ \\ Rebeca Carolinne Castro Gomes ${ }^{* * * *}$
}

\begin{abstract}
RESUMO
Este artigo discute a representação do eu e sua relação com as novas "tecnologias do olhar". Convidaram-se usuários do Facebook a escolher uma autoimagem de seu perfil e responder questóes sobre tal escolha (significado, relação com a história de vida, razões para partilhar, reações dos amigos, estímulo para novas postagens). Foram analisadas tematicamente as respostas de 33 jovens, em sua maioria, universitários entre 20 e 30 anos. Os achados destacam imagens e argumentos associados à diversão, felicidade e autenticidade, valores disseminados na sociedade de consumo. Estar no Facebook envolve o monitoramento da atividade (própria e alheia) de partilhar imagens pessoais e observar a sua recepção nesse espaço. Essas são utilizadas para transmitir uma imagem pessoal desejável, que exprime o estilo de vida e não a história de vida do usuário. Conclui-se que o compartilhamento de imagens nas redes sociais desempenha papel decisivo na construção da identidade pessoal hoje.
\end{abstract}

Palavras-chave: Cultura visual. Fotografias digitais. Representação do eu. Redes sociais. Facebook.

\footnotetext{
Texto recebido em 10 de março de 2015 e aprovado para publicação em 22 de outubro e 2015.

Este trabalho contou com o apoio da Funcap, CNPq, Capes e FNDE, em forma de bolsas de Mestrado, Iniciação Científica, Programa de Educação Tutorial (PET) e Jovens Talentos concedidas às autoras.

*Doutora em Sociologia, professora titular do Departamento de Psicologia da Universidade Federal do Ceará (UFC). E-mail: idilvapg@gmail.com.

**Doutoranda e mestra em Psicologia pela UFC, bacharel em Comunicação Social (Publicidade Propaganda) pela mesma universidade, foi bolsista Funcap.

***Graduada em Psicologia pela UFC, foi bolsista CNPq de Iniciação Científica do Curso de Psicologia da mesma universidade, psicóloga.

**** Graduada em Psicologia pela UFC, foi bolsista Capes Jovens Talentos do Curso de Psicologia da UFC e bolsista do Programa de Educação Tutorial (PET Psicologia) (FNDE), psicóloga.

***** Mestra e graduada em Psicologia pela UFC, foi Bolsista CNPq de Iniciação Científica do Curso de Psicologia da mesma universidade, psicóloga.
} 


\begin{abstract}
This paper discusses the presentation of self and its relation to new "gazing technologies". Facebook users were invited to choose a personal photo they had posted on their profiles and were asked about their choice (its meaning, relation to life history, reasons to post, friends' reactions, motivation for posting new images). The answers from 33 Facebook users, mostly college students, 20 to 30 years old, received thematic analysis. The analysis highlighted images and arguments associated to entertainment, happiness and authenticity, dominant values in consumer society. To be on Facebook involves the monitoring of one's own or someone else's activity of sharing personal images and observing their reception on that space. The images are used mainly to convey a desirable self-portrait that expresses a person's life style but not her/his life story. We conclude that sharing personal photos on social networking sites plays an important role in today's personal identity construction.
\end{abstract}

Keywords: Visual culture. Digital photographs. Presentation of self. Social networking sites. Facebook.

\title{
RESUMEN
}

Este trabajo aborda la representación del yo y su relación con las nuevas "tecnologías del mirar". Se invitó a usuarios de Facebook a elegir una autoimagen de su perfil y a responder algunas preguntas sobre esa elección (significado, relación con historia de vida, razones para compartir, reacciones de amigos, estímulo para nuevas publicaciones). Fueron analizadas temáticamente las respuestas de 33 jóvenes, en su mayoría estudiantes universitarios entre 20 y 30 años. Entre los resultados destacan las imágenes y los argumentos asociados con diversión, felicidad y autenticidad, valores dominantes en la sociedad de consumo. Estar en Facebook implica observar la actividad (propia y de los otros), compartir fotos personales y seguir su recepción en este espacio. Se usan las fotos para transmitir una imagen personal deseable que expresa el estilo de vida pero no la historia de vida del usuario. Se concluye que las fotos compartidas en las redes sociales tienen un papel crucial en la construcción de la identidad personal en la actualidad.

Palabras-clave: Cultura visual. Fotografías digitales. Representación del yo. Redes sociales. Facebook.

\section{INTRODUÇÃO}

Tas últimas décadas, as tecnologias de informação e comunicação, especialmente as que permitem o funcionamento das redes sociais 1 virtuais, vem ampliando, de forma avassaladora, a transmissão de dados a distância, resultando num novo e poderoso espaço de comunicação, 
sociabilidade e subjetivação. As redes sociais virtuais potencializam as múltiplas formas de apresentação do "eu" nesta era tecnológica, promovendo cada vez mais os encontros interativos e instantâneos por computadores, celulares e tablets. A cada dia, mais pessoas se conectam por meio desses dispositivos, expondo e compartilhando, diariamente e em tempo real, frases, textos e imagens sobre sua vida pessoal e praticamente qualquer assunto que lhe interesse. Somente no Brasil, uma das redes sociais mais importantes, o Facebook, atingiu, em 2018, 127 milhões de usuários ativos mensais, posicionando o país entre os maiores marcados mundiais em número de usuários de internet no mundo (Banks, 2014; Oliveira, 2018).

Estudiosos têm observado que o conjunto de transformações tecnológicas na vida contemporânea e, em particular, nos sites de redes sociais, tem efeito sobre a própria construção da identidade pessoal, favorecendo especialmente os modos visuais de representação de si (Zhao, Grasmuck \& Martin, 2008; House, 2009; Van Dijck, 2008; Hum et al., 2011; Schafie, Nayan \& Osman, 2012; Goodings, 2012). O indivíduo passa a apresentar-se aos outros principalmente por meio de fotografias e vídeos intensamente compartilhados nas redes sociais. Além disso, estudos recentes vêm assinalando outros efeitos das tecnologias digitais hoje: alterações nos modos de revelar a intimidade e tópicos sensíveis ou estigmatizantes sobre si (Nosko, Wood \& Molema, 2010; Livingstone, 2012), de monitorar e analisar seus laços sociais (Karakayali \& Kilic, 2013; Stutzman, Vitak, Ellison, Gray \& Lampe, 2012) e de criar uma persona pessoal ou profissional (Van Dijck, 2013).

Tais reflexões sugerem que atualmente a pergunta "quem sou eu?" é respondida de forma substancialmente diferente daquela implicada nas confissões dos diários íntimos, artefatos pertencentes ao moderno gênero autobiográfico e que pressupõem um eu profundo que se pode sondar e manter em segredo (Sibilia, 2008). De fato, há uma relação estreita e dialética entre as tecnologias (materiais, processos, instrumentos) historicamente disponíveis e a construção do eu. As práticas de si que a burguesia adotou nos séculos XVIII e XIX (introspecção, confissões, narrativas autobiográficas coerentes sobre um eu interior concebido como uma totalidade coesa, diários escritos na solidão) não parecem mais mobilizar a expressão individual e dão lugar a novas formas de compreensão e apresentação de si disseminadas no contexto do capitalismo pós-industrial, da sociedade de consumo e da cultura da imagem.

Nosso estudo tem como ponto de partida os significados que os usuários do Facebook atribuem às suas atividades no ambiente virtual, focalizando especialmente o compartilhamento de fotos pessoais nessa rede social. Investiga a "representação do eu" entre usuários dessa rede social, com base na seguinte pergunta norteadora: como as pessoas empregam fotografias pessoais para afirmar quem são no Facebook? O conceito de representação do eu aqui adotado (Goffman, 2009) refere-se "a toda atividade de um indivíduo que se passa num período caracterizado por sua presença contínua diante de um grupo particular de observadores e que tem sobre estes alguma influência” (p. 29). A perspectiva 
dramatúrgica de Goffman explora a ordem interacional e seus rituais que permitem aos indivíduos atribuir sentido às coisas e agir conforme esses sentidos emergentes. Nessa visão, não há um sentido fixo, mas sentidos que emergem da atividade do ator social diante de outros e das impressões produzidas entre as partes. O que a pessoa faz (o modo como atua) estabelece quem ela é. O self, portanto, é o sentido estabelecido pela atividade daquele que se apresenta diante de outros e pelas atividades dos outros em resposta a essa apresentação. Isso confere um aspecto contingente e performático à noção de "quem sou". Aplicada ao estudo do self on-line, essa visão entende que as pessoas estrategicamente se apresentam nas redes sociais de um modo compreensível para outros membros da comunidade virtual. Os indivíduos tentam, conscientemente ou não, dar uma resposta ao contexto interativo, ajustando continuamente informações referentes à sua pessoa, conforme as reaçōes de seus interlocutores (Goodings, 2012; Ribeiro \& Braga, 2012).

As interações em sites de redes sociais implicam o manejo ou "manipulação da impressão", isto é, a atividade dirigida para controlar e regular informações de modo a influenciar as impressóes formadas por uma audiência. Os usuários dos sites de redes sociais empenham-se em controlar a impressão que seus contatos na rede têm de pessoas (os próprios usuários, amigos e mesmos inimigos), de objetos, eventos (por exemplo, realizaçóes acadêmicas e profissionais) e ideias (por exemplo, visões políticas, filosofia de vida). Quando as pessoas manejam a impressão sobre si mesmas, essa atividade também pode ser chamada de "representação de si" ou "representação do eu" (tradução que se estabeleceu do termo original em língua inglesa, self-presentation). Tal conceito refere-se às ações estratégicas que as pessoas realizam para criar e manter uma autoimagem positiva e desejável para outros. Autoimagens favoráveis (ser atraente, correto, interessante, popular, entre outras) podem ser alcançadas por meio de táticas orientadas para objetivos interpessoais de curto prazo, tais como publicidade e futuras interaçóes. Considerando a natureza pública das redes sociais, seus usuários tendem a se empenhar no cuidadoso monitoramento de sua imagem (Rosenberg \& Egbert, 2011).

Zhao, Grasmuck e Martin (2008) distinguem três modos de expressão de si que variam em grau de visibilidade no Facebook. A forma mais implícita, o self visual, tende a se projetar em imagens do usuário entre seus pares, sorrindo e se divertindo, a fim de gerar impressões desejáveis entre seus expectadores acerca de sua sociabilidade. Além do self visual (o "self como ator social"), outras estratégias gradativamente mais explícitas incluem a enumeração das preferências, interesses e hobbies que o usuário acha que o definem ("self cultural" ou "self como consumidor"), e a narração ou descrição mais direta de quem o usuário acha que é em sinopses verbais sobre sua pessoa, o "self em primeira pessoa" (Zhao et al., 2008, p. 1825). As fotos digitais no Facebook operam como as afirmações de identidade mais implícitas e mais numerosas, que envolvem interações em torno da postagem das imagens principais do perfil, dos álbuns e outras feitas pelo próprio usuário e das imagens veiculadas por seus contatos que contribuem com 
conteúdos no seu espaço. Essas fotos são constantemente atualizadas, permitindo ao usuário certa flexibilidade e manipulação na apresentação de si, o que leva à questão de se os perfis do Facebook exprimem impressões fidedignas sobre seus donos (Wilson, Gosling \& Graham, 2012). Outro ponto levantado por Wilson, Gosling e Graham (2012), em sua revisão sobre as pesquisas nessa rede social, é que "pressuposições sobre a audiência percebida bem como normas culturais também podem influenciar como usuários se retratam no Facebook" (p. 210).

Reconhecendo a importância da exibição visual de si e da conectividade nos processos identitários em curso nas redes sociais, nosso foco dirige-se para a compreensão, para seus usuários, dos significados das imagens postadas e partilhadas na rede. Nosso estudo, a princípio, levanta as percepções que alguns de nossos contatos, usuários do Facebook, tem sobre suas escolhas e razóes para partilhar imagens na rede. Em seguida, procura discutir as percepçôes dos participantes do estudo, problematizando alguns resultados da análise, à luz da literatura recente.

\section{METODOLOGIA}

A pergunta central que orienta nossa incursão no Facebook é: como usuários do Facebook compreendem e justificam as suas postagens de imagens autorreferentes na rede? O objetivo do estudo exploratório é analisar as percepçóes dos usuários sobre as próprias imagens escolhidas para representar "quem são", seus motivos, reações de seus contatos e suas respostas às reações alheias. Explicando os objetivos da pesquisa para nossos próprios contatos no Facebook, nós os convidamos a responder a algumas questões sobre sua representação de si nessa mídia social. O contato foi realizado por meio da própria página do Facebook, por mensagens pessoais ou e-mails que explicavam a natureza e metodologia do estudo. Aceitaram o convite 33 pessoas, de ambos os sexos: 25 na faixa entre 20 e 30 anos; 5, de 10 a 19 anos; e 3 com idade não informada. A maioria eram estudantes universitários, e os demais, estudantes de ensino médio.

$\mathrm{O}$ instrumento consistiu de uma solicitação para escolher uma imagem publicada em seu perfil no Facebook, seguida de cinco perguntas relacionadas a essa escolha:

a) entre as fotografias pessoais que você vem postando na sua página do Facebook, por favor, escolha uma imagem representativa de quem você é, isto é, uma imagem que exprima melhor sua identidade pessoal, como você se vê ou se sente. Uma imagem que seja "a sua cara".

b) qual é a história da imagem escolhida? Onde, quando e como a fotografia foi tirada? Quem a tirou? Que significado ela tem?

c) como essa imagem ajuda seus amigos e contatos na rede a conhecer a sua história?

d) por que você partilhou essa imagem?

e) como seus amigos no Facebook reagiram a essa imagem?

f) as respostas dos seus amigos no Facebook a essa imagem lhe estimularam a produzir e partilhar novas imagens parecidas com essa? 
As imagens escolhidas (referentes ao item 1 do instrumento) foram descritas com base em alguns critérios, tais como local e circunstância de produção da imagem e características do retratado na imagem, tais como sexo, número de sujeitos (só, casal/2 indivíduos, em grupo, outra), nível de espontaneidade (espontâneo, posado, não se aplica, participante não retratado/outra), expressão facial (sorridente, sério/não olha para a câmera, não se aplica/imagem de paisagem, rosto não aparece/outra). Os dados verbais (referentes às questôes $2 \mathrm{a}$ 6) receberam codificação temática. Os códigos emergentes foram agrupados em categorias mais abrangentes para posterior discussão à luz da literatura.

\section{RESULTADOS E DISCUSSÃO}

\subsection{Descrição geral do tipo de imagem produzida}

As imagens escolhidas em resposta à primeira pergunta foram descritas e categorizadas quanto ao local e circunstância de produção e características do retratado na imagem. São, em sua maioria, imagens posadas dos próprios participantes, em que estão parados (sem atividade física) e sozinhos. Esses resultados aproximam-se de estudo anterior analisando imagens de 150 usuários de Facebook, estudantes universitários de ambos os sexos nos Estados Unidos (Hum et al., 2011). Os usuários tendem a construir sua autoimagem de forma mais implícita do que explícita, "mostrando" pelas fotos, mais do que "dizendo" diretamente quem são. Essas imagens, uma vez objeto de aprovação ou desaprovação social, são ajustadas segundo as respostas dos seus contatos.

Um aspecto a destacar sobre o local e circunstância de produção das imagens é que mais de $63 \%$ dos informantes remetem a situaçôes de entretenimento, em que estão felizes, divertindo-se em locais não habituais, em viagem ou fora do ambiente doméstico, que julgam apropriado compartilhar segundo as normas culturais de exibição pessoal on-line e sua percepção do que é socialmente desejável. Nas imagens de nossos participantes, a expressão facial exibe um sorriso, sinalizando alegria e bem-estar (também presente nas imagens em grupo) que tende a ser valorizado pelos retratados na sua apresentação de si on-line e associado a traços de personalidade ou estilo de vida. Esse resultado também apoia achados anteriores, que incluem o de Zhao et al. (2008) sobre a impressão que estrategicamente tais fotos ensejam acerca da extensão dos laços sociais dos retratados, bem como sua relação com identidades "possíveis e esperadas" (hopedfor possible selves). Essas são identidades socialmente desejáveis que o indivíduo gostaria de estabelecer e que podem ser impedidas em situações face a face (por exemplo, por exibição involuntária de traços indesejáveis, como timidez e defeitos físicos). No Facebook, tais impedimentos podem ser contornados por uma escolha criteriosa do que postar. 
Tabela 1. Descrição da imagem produzida (local e circunstância de produção)

\begin{tabular}{|c|c|c|c|c|}
\hline Categorias & Circunstância & Atributos & $\begin{array}{c}\text { Frequência } \\
\text { parcial } \\
\%\end{array}$ & $\begin{array}{c}\text { Frequência total } \\
\%\end{array}$ \\
\hline \multirow{7}{*}{$\begin{array}{l}\text { Em casa } \\
\mathrm{N}=6\end{array}$} & \multirow{2}{*}{$\begin{array}{l}\text { Fazendo coisas } \\
\text { habituais }\end{array}$} & No quarto & \multirow[t]{3}{*}{9,09} & \multirow[t]{7}{*}{18,18} \\
\hline & & \multirow[t]{2}{*}{ No banheiro } & & \\
\hline & $\mathrm{N}=3$ & & & \\
\hline & Antes de sair & Arrumando-se & 3,03 & \\
\hline & $\mathrm{N}=1$ & & & \\
\hline & Momento especial & Com familiares & 6,06 & \\
\hline & $\mathrm{N}=2$ & Seu aniversário & & \\
\hline \multirow{7}{*}{$\begin{array}{l}\text { Em viagem } \\
N=10\end{array}$} & \multirow{5}{*}{$\begin{array}{l}\text { Diversão } \\
\mathrm{N}=8\end{array}$} & - Em família & 24,24 & \multirow[t]{7}{*}{30,30} \\
\hline & & $\begin{array}{l}\text { - Para visitar lugares } \\
\text { com amigos }\end{array}$ & & \\
\hline & & - Com namorado & & \\
\hline & & $\begin{array}{l}\text { - Para eventos } \\
\text { musicais (como } \\
\text { artista, como } \\
\text { audiência) }\end{array}$ & & \\
\hline & & $\begin{array}{l}\text { - Para eventos } \\
\text { esportivos (como } \\
\text { jogador; como } \\
\text { torcedor) }\end{array}$ & & \\
\hline & $\begin{array}{l}\text { Fins religiosos/ } \\
\text { míticos }\end{array}$ & $\begin{array}{l}\text { - Jornada da } \\
\text { Juventude }\end{array}$ & 6,06 & \\
\hline & $\mathrm{N}=2$ & $\begin{array}{l}\text { - Cerimônias } \\
\text { xamanistas }\end{array}$ & & \\
\hline \multirow{9}{*}{$\begin{array}{l}\text { Fora de casa/ } \\
\text { Na cidade } \\
N=16\end{array}$} & \multirow{5}{*}{$\begin{array}{l}\text { Diversão } \\
\mathrm{N}=13\end{array}$} & - Em passeio no fim & 39,39 & \multirow[t]{9}{*}{48,48} \\
\hline & & de semana & & \\
\hline & & $\begin{array}{l}\text { - Em seu hobby ou } \\
\text { esporte }\end{array}$ & & \\
\hline & & $\begin{array}{l}\text { - Numa festa ou } \\
\text { seguindo para a festa }\end{array}$ & & \\
\hline & & $\begin{array}{l}\text { - No ambiente } \\
\text { escolar/universitário }\end{array}$ & & \\
\hline & Estudo ou trabalho & -Sala de aula & 6,06 & \\
\hline & $\mathrm{N}=2$ & $\begin{array}{l}\text { - Atividade } \\
\text { extracurricular }\end{array}$ & & \\
\hline & $\begin{array}{l}\text { Evento religioso/ } \\
\text { espiritual }\end{array}$ & \multirow[t]{2}{*}{ Missa de formatura } & \multirow[t]{2}{*}{3,03} & \\
\hline & $\mathrm{N}=1$ & & & \\
\hline $\begin{array}{l}\text { Não } \\
\text { informado }\end{array}$ & & & \multirow[t]{2}{*}{3,03} & \multirow[t]{2}{*}{3,03} \\
\hline $\mathrm{N}=1$ & & & & \\
\hline
\end{tabular}

Fonte: elaborada por Idilva Maria Pires Germano. 
Tabela 2. Descrição da imagem produzida (características do retratado na imagem)

\begin{tabular}{|c|c|c|}
\hline Categorias & Atributos & $\%$ \\
\hline \multirow{4}{*}{$\begin{array}{l}\text { Número de pessoas } \\
\text { retratadas }\end{array}$} & Participante está só & 63,63 \\
\hline & $\begin{array}{l}\text { Participante com } \\
\text { mais uma pessoa }\end{array}$ & 12,12 \\
\hline & $\begin{array}{l}\text { Participante em } \\
\text { grupo }\end{array}$ & 15,15 \\
\hline & $\begin{array}{l}\text { Participante não } \\
\text { retratado/outra }\end{array}$ & 9,09 \\
\hline \multirow{4}{*}{$\begin{array}{l}\text { Nível de } \\
\text { espontaneidade }\end{array}$} & Posando & 72,72 \\
\hline & Espontâneo & 18,18 \\
\hline & $\begin{array}{l}\text { Não se aplica } \\
\text { (imagens de } \\
\text { paisagem) }\end{array}$ & 6,06 \\
\hline & $\begin{array}{l}\text { Participante não } \\
\text { retratado/outra }\end{array}$ & 3,03 \\
\hline \multirow[t]{4}{*}{ Expressão facial } & Sorridente & 63,63 \\
\hline & $\begin{array}{l}\text { Sério/não olha para } \\
\text { a câmera }\end{array}$ & 21,21 \\
\hline & $\begin{array}{l}\text { Não se aplica } \\
\text { (paisagem) }\end{array}$ & 6,06 \\
\hline & $\begin{array}{l}\text { Rosto não aparece/ } \\
\text { outra }\end{array}$ & 9,09 \\
\hline
\end{tabular}

\subsection{História e significado da imagem}

Em resposta à questão 2 do instrumento, os participantes descreveram o contexto de produção da imagem ou contaram uma breve história, conferindolhe alguns valores e significados. As respostas de cada participante receberam uma ou mais categorias, gerando, ao final da codificação, 49 argumentos, distribuídos em sete categorias.

O significado da imagem é justificado principalmente a partir de valores estéticos (porque saiu bonito ou bonita na foto ou por sua qualidade estética) ou expressivos (por exprimir sentimentos, emoções e estados mentais também positivos, tais como felicidade, paz, autoestima, orgulho). Desse modo, a tendência é figurarem-se como pessoas belas, dentro dos padrões estéticos vigentes, "divertidas" e "felizes", portanto, que aguardam ser reconhecidas como tal. Essa representação de si na rede social fornece um conjunto de informações sobre como o participante gostaria de ser compreendido por amigos e seguidores. São informações ou pistas selecionadas para administração da impressão alheia, aqui sintetizada numa frase hipotética: "divirto-me, portanto, sou feliz". Essa 
impressão é negociada continuamente mediante o fluxo de postagens de teor e significado semelhante. Os resultados obtidos alinham-se aos obtidos noutros estudos semelhantes e evocam o monitoramento constante e comparativo que usuários de redes sociais como Facebook fazem de sua imagem e da imagem alheia, muitas vezes em resposta à possibilidade de que os outros sejam mais felizes que eles mesmos (Chou \& Edge, 2012).

O convite incessante à exposição e a promessa de felicidade na cultura das redes sociais ecoam nos retratos e autorretratos (os célebres selfies) que nossos informantes exibem no Facebook. A frequente menção à "diversão", nas respostas colhidas, torna visível, por contraste, a ocultação dos sentimentos negativos ou momentos introspectivos. Esses são expugnados das redes sociais virtuais, evidenciando, "agora como nunca antes, uma autoexpressão e uma consciência estilizada de si, e da vida, que o capital simbólico dos objetos de consumo ajuda a definir" (Pina, 2005, p. 7). O sorriso e a diversão são os principais conteúdos imagéticos das fotografias compartilhadas em rede entre os participantes deste estudo e remetem a uma autoimagem estetizada, próxima à da publicidade, que responde aos imperativos de um "eu" idealizado a ser desejado e consumido. A participante 2 diz: "É sempre bom ser elogiada e sentir que as pessoas perceberam a sua felicidade naquele momento". A felicidade, uma vez desejada socialmente, tem o status de ser publicável. Por essa razão, imagens que a ela fazem referência são preferencialmente publicadas e dotam o sujeito que a manifesta de capital social (Carrera, 2014).

Nas falas de nossos participantes, contudo, tais idealizações surgem, algumas vezes, matizadas por meio de um discurso da autenticidade, uma necessidade de "parecer natural", digno de confiança. Percebe-se, assim, certa oposição ao programado, ao dissimulado, ao artificial. A explicação da participante 12 é sintomática: "Gosto de, às vezes, tirar fotos, quando estou arrumada ou quando me sinto bonita ou diferente. Tirei eu mesma, em casa, no meu quarto. Eu gostei, porque sai sorrindo aparentemente espontânea". Como afirma Sibilia (2008), "Quanto mais a vida cotidiana é ficcionalizada e estetizada com recursos midiáticos, mais avidamente se procura uma experiência autêntica ou verdadeira. Busca-se o realmente real, algo não encenado - ou, pelo menos, que assim pareça" (p. 196).

Essa tensão entre "ser" e "parecer", entre "melhorar" a autoimagem e simultaneamente apresentar uma autoimagem fidedigna, não passa despercebida dos próprios usuários, uma vez que, durante o estudo, são instados a refletir sobre sua própria atividade na rede social, portanto se tornando atentos às contradições, objeções e críticas potenciais. É assim que alguns informantes recusam a imagem como portadora de representatividade do eu e um deles chega a discorrer contra a felicidade ilusória nas redes sociais num discurso bem afinado com essa literatura crítica: 
Procuro postar no Face fotos em ocasióes alegres, divertidas, em que estou me sentindo feliz e segura ao lado de familiares e amigos, entretanto não demonstro publicamente imagens que poderiam representar o que é vivido em ocasiōes opostas: a tristeza e a insegurança. Acredito que nas redes sociais predominam uma imagem "vendida" de uma vida perfeita e de uma completa felicidade, algo que faz com que você se cobre por não condizer perfeitamente com tudo isso que é propagado e então, a "saída" encontrada para tentar passar essa imagem da vida perfeita e obter a aprovação das outras pessoas é, como citei anteriormente, postar apenas os momentos felizes (Participante 8, sexo feminino).

Tabela 3. História e significado da imagem

\begin{tabular}{|c|c|c|c|}
\hline Categorias & Dimensões/atributos & Exemplos de respostas & $\%$ \\
\hline $\begin{array}{l}\text { Valor ético } \\
\text { Quando a } \\
\text { imagem é julgada } \\
\text { por evocar } \\
\text { valores éticos } \\
\text { e ideais, isto é, } \\
\text { sobre o que é } \\
\text { "bom”, "justo" e } \\
\text { "desejável" para si } \\
\text { e para os outros. }\end{array}$ & $\begin{array}{l}\text { Liberdade } \\
\text { Determinação/Força } \\
\text { de vontade } \\
\text { Autenticidade } \\
\text { Amizade, união }\end{array}$ & $\begin{array}{l}\text { "Estava completamente } \\
\text { concentrada na liberdade } \\
\text { de poder mandar no meu } \\
\text { tempo e no meu corpo"; } \\
\text { "O significado dessa seria o } \\
\text { esporte que sempre foi e é } \\
\text { muito importante pra mim } \\
\text { [...] e a amizade, a uniāo, } \\
\text { a companhia de um grupo } \\
\text { muito querido." }\end{array}$ & 6,18 \\
\hline $\begin{array}{l}\text { Valor estético } \\
\text { Quando a } \\
\text { imagem é } \\
\text { julgada por seu } \\
\text { valor estético, } \\
\text { isto é, quando } \\
\text { o participante } \\
\text { afirma que } \\
\text { a imagem } \\
\text { apresenta valores } \\
\text { que a tornam } \\
\text { "bela". }\end{array}$ & $\begin{array}{l}\text { Beleza do retratado } \\
\text { Beleza das formas } \\
\text { Imagem captura a } \\
\text { realidade de forma } \\
\text { natural, espontânea } \\
\text { Fidedignidade } \\
\text { Verossimilhança } \\
\text { Mistério, } \\
\text { encantamento, magia }\end{array}$ & $\begin{array}{l}\text { "Representa também uma } \\
\text { foto fidedigna de como eu } \\
\text { sou fisicamente, pois estou } \\
\text { bem natural, sorrindo." } \\
\text { "Eu gostei, porque saí } \\
\text { sorrindo aparentemente } \\
\text { espontânea." } \\
\text { "O significado dela para } \\
\text { mim [...], pois foi a } \\
\text { primeira foto minha em } \\
\text { que percebi o que... quanto } \\
\text { tenho um sorriso bonito e } \\
\text { quanto eu gosto dele." } \\
\text { "E é especial porque foi } \\
\text { espontânea. [...] Ela tem } \\
\text { algo que me encanta." }\end{array}$ & 28,57 \\
\hline
\end{tabular}




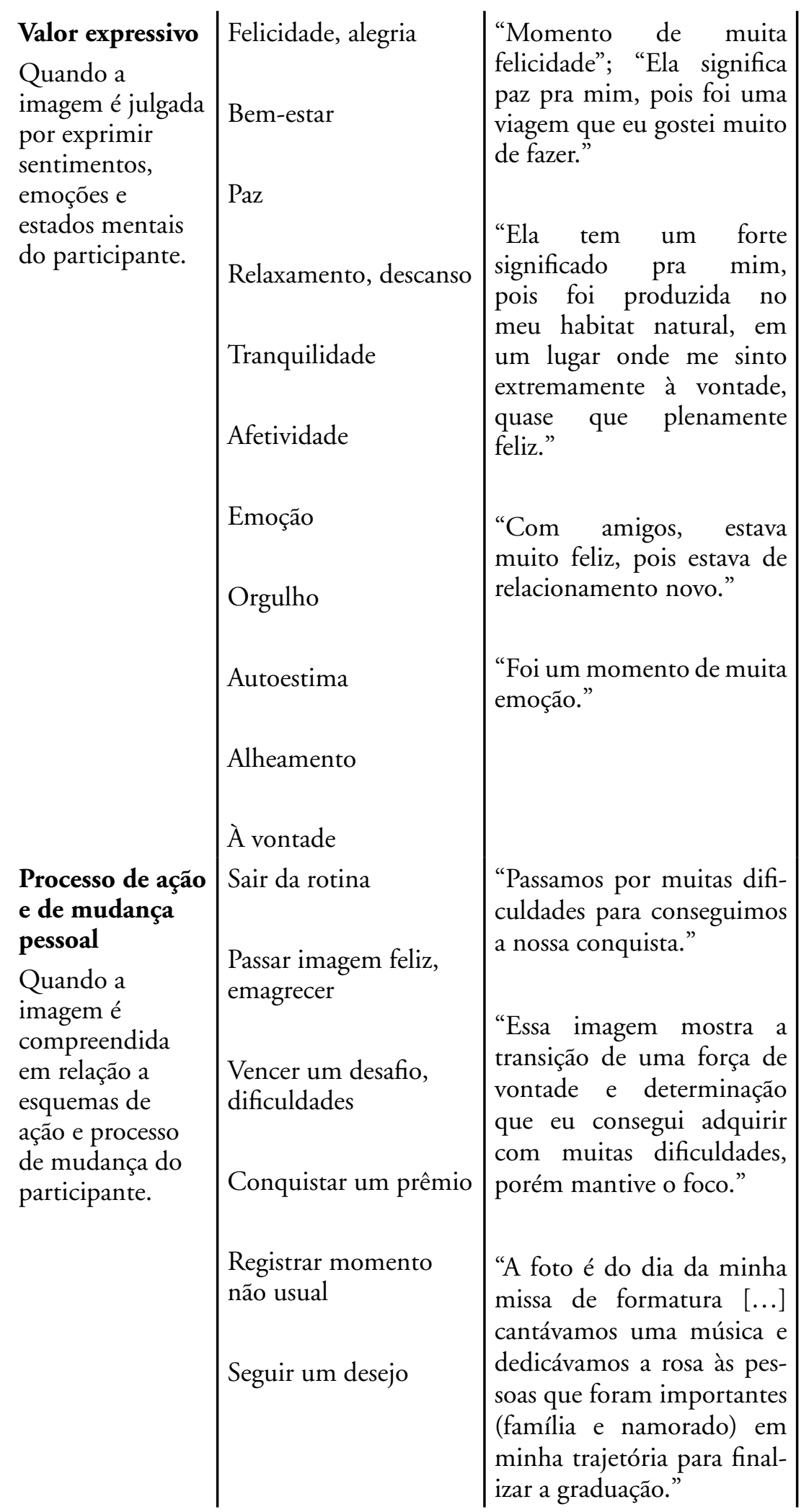




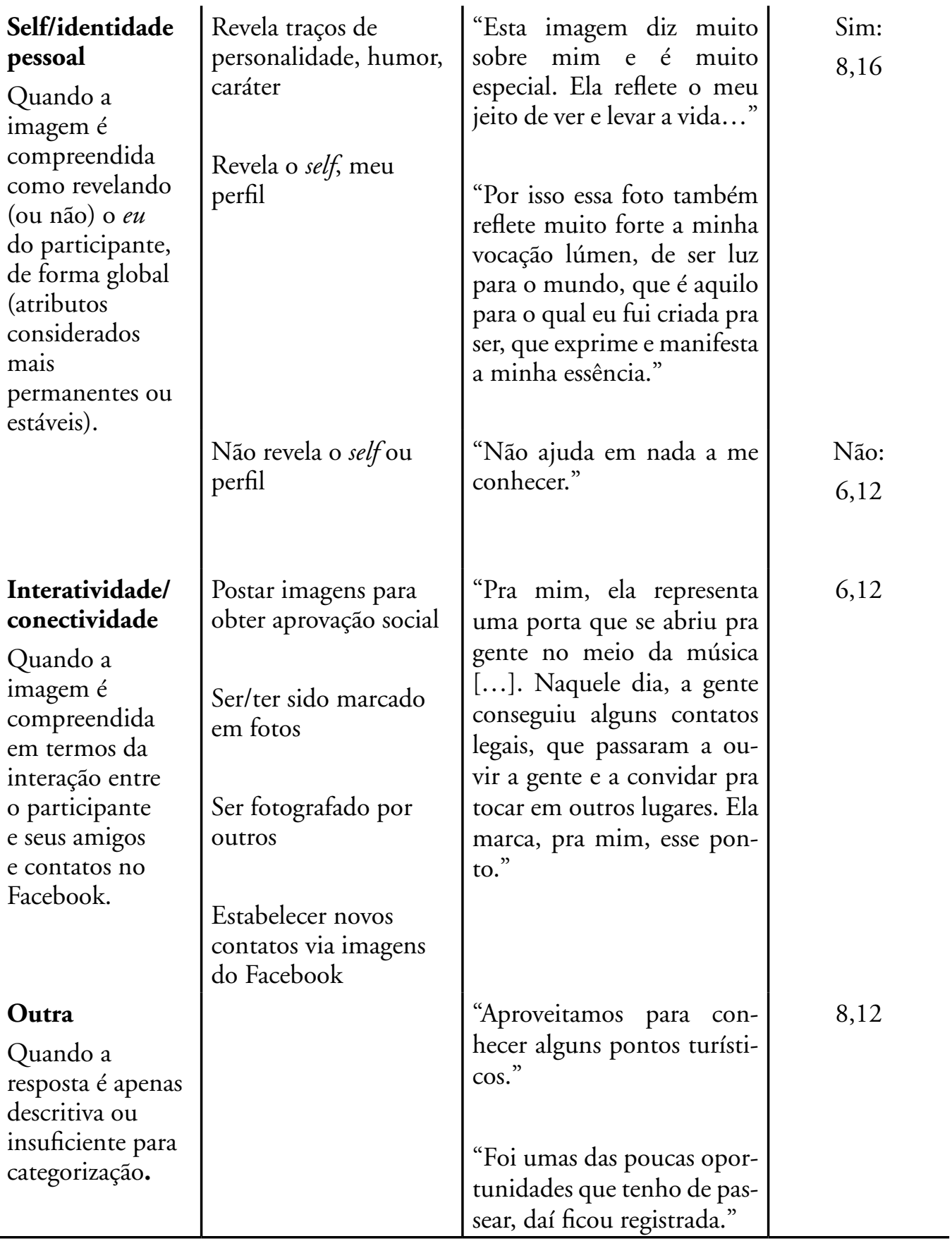

Fonte: elaborada por Idilva Maria Pires Germano. 


\subsection{Percepção de que a imagem representa o retratado para os outros}

As respostas de cada participante ao item 3 receberam uma ou mais categorias, gerando, ao final da codificação, 47 argumentos, distribuídos em sete categorias, sobre o que e como acham que a imagem escolhida representa sua história de vida e sua pessoa. Os participantes tendem a compreender que a imagem de si permite conhecer seu estilo de vida, suas preferências, gostos e outras pistas para a inferência da audiência, mas não efetivamente sua história ou biografia, algo que exigiria certo grau de conhecimento pessoal (não virtual) e reconhecimento mútuo. Parte significativa das respostas indica que os usuários percebem que, em sua rede de contatos, o grau de familiaridade é variável e que as pessoas íntimas off-line teriam mais recursos para conhecer sua história. Com isso, evocam a superficialidade do self visual on-line e o apelo à construção de identidades "possíveis e esperadas", sugerindo que o usuário percebe o uso estratégico das fotos na apresentação pessoal em que ele e seus contatos se engajam. Os usuários reconhecem que se apresentam de uma forma idealizada, realçando suas qualidades e ocultando pontos fracos, de uma forma que eles aspiram ser off-line.

De fato, poucas fotografias foram compreendidas autobiograficamente, isto é, numa perspectiva de articulação entre eventos e experiências levando a uma visão de "quem sou" hoje. Como afirma Roberts (2011), rever um autorretrato é mais que simplesmente

Reavaliar os elementos de uma imagem particular ("como era nossa aparência"), mas parte de um processo de construir a história pessoal [...] Ver uma autoimagem está implicado na formação de si, onde usamos o visual e outras dimensões dos sentidos, sentimentos e emoçōes (p. 25).

O olhar autobiográfico, incorporado nos tradicionais álbuns de família que, vez por outra, eram revisitados para rememoração particular ou conjunta, aparece com raridade, sinalizando que mudou a forma como produzimos e consumimos fotografias na era digital, em especial, nas redes sociais. 
Tabela 4. Percepção de que a imagem representa o participante para os outros

\begin{tabular}{|c|c|c|c|}
\hline Categorias & Dimensóes & $\begin{array}{l}\text { Exemplos de } \\
\text { respostas }\end{array}$ & $\%$ \\
\hline Estilo de vida & $\begin{array}{l}\text { Imagem revela gosto } \\
\text { pela natureza, por certos } \\
\text { ambientes, lugares; hábito } \\
\text { de curtir a vida; lazer de fim } \\
\text { de semana; prazer de viajar } \\
\text { e conhecer lugares novos; } \\
\text { preferências. }\end{array}$ & $\begin{array}{l}\text { "Essa imagem ajuda } \\
\text { meus amigos [...] a } \\
\text { perceber que gosto } \\
\text { de natureza. De } \\
\text { curtir a vida." } \\
\text { "Acredito que as } \\
\text { fotos revelam suas } \\
\text { preferências e seu } \\
\text { estilo de vida, então } \\
\text { penso que aproxima } \\
\text { mais as pessoas } \\
\text { dentro de um campo } \\
\text { de preferências." } \\
\\
\text { "A foto ajuda meus } \\
\text { amigos a conhecer } \\
\text { a minha história } \\
\text { porque mostra o que } \\
\text { eu costumo fazer nos } \\
\text { finais de semana." }\end{array}$ & 29,78 \\
\hline $\begin{array}{l}\text { Estado de espírito/ } \\
\text { humor }\end{array}$ & $\begin{array}{l}\text { Imagem revela alegria, } \\
\text { felicidade, extroversão, estar } \\
\text { de bem com a vida, realização. }\end{array}$ & $\begin{array}{l}\text { "Transmite o meu } \\
\text { estado de espírito, } \\
\text { sempre alegre, feliz, } \\
\text { rodeada de amigos e } \\
\text { conhecendo lugares } \\
\text { novos." } \\
\text { "Eu acho que } \\
\text { exprime um pouco } \\
\text { o que eles pensam } \\
\text { de mim: uma pessoa } \\
\text { extrovertida." }\end{array}$ & 12,76 \\
\hline
\end{tabular}




\begin{tabular}{|c|c|c|}
\hline $\begin{array}{l}\text { Momentos } \\
\text { especiais }\end{array}$ & $\begin{array}{l}\text { Imagem revela importância de } \\
\text { certos momentos (celebração, } \\
\text { vitórias acadêmicas, } \\
\text { esportivas, pessoais). }\end{array}$ & $\begin{array}{l}\text { "A imagem expressou } \\
\text { bem, meu namorado } \\
\text { longe na França, } \\
\text { representou o } \\
\text { reencontro... eu } \\
\text { indo lá pra matar a } \\
\text { saudade." } \\
\text { "É uma imagem de } \\
\text { um evento familiar } \\
\text { importante, que } \\
\text { traz alegria, mais } \\
\text { um momento que } \\
\text { estou junto a minha } \\
\text { família presente em } \\
\text { todos os momentos } \\
\text { importantes da } \\
\text { minha vida." }\end{array}$ \\
\hline Sociabilidade & $\begin{array}{l}\text { Imagem revela inclinação para } \\
\text { divertir as pessoas, estar com } \\
\text { pessoas e estabelecer contatos, } \\
\text { buscar reconhecimento } \\
\text { profissional/artístico/ } \\
\text { esportivo, postar coisas } \\
\text { agradáveis e interessantes para } \\
\text { os outros. }\end{array}$ & $\begin{array}{l}\text { "Também fica fácil } \\
\text { de alguém me recon- } \\
\text { hecer como musicis- } \\
\text { ta, e isso pode ajudar } \\
\text { na obtenção de con- } \\
\text { tatos." } \\
\text { "Muitas pessoas } \\
\text { sabem que jogo vôlei } \\
\text { e mostrando resul- } \\
\text { tados se torna mais } \\
\text { visível." }\end{array}$ \\
\hline
\end{tabular}




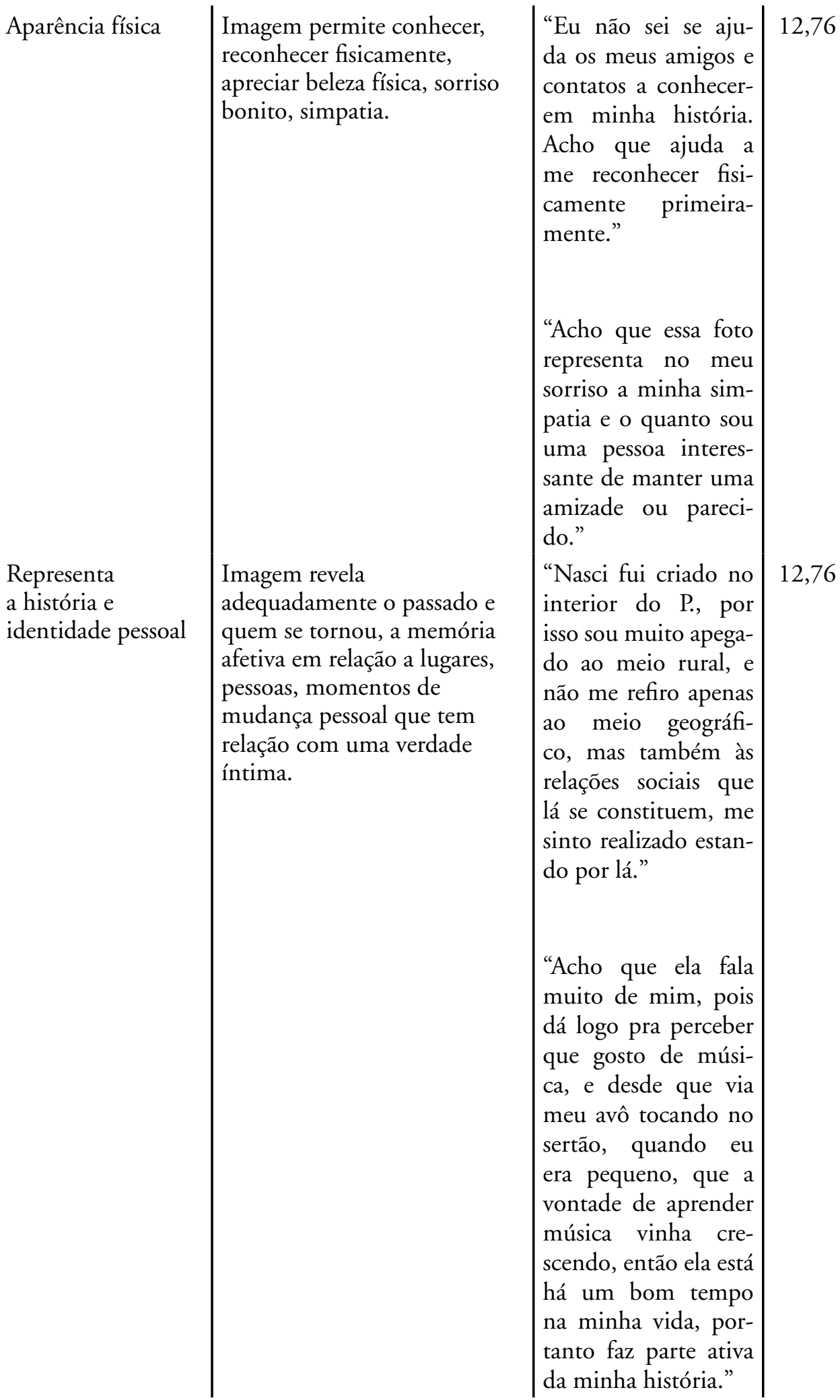




\begin{tabular}{l|l|l|l}
$\begin{array}{l}\text { Não representa/ } \\
\text { representa pouco } \\
\text { a história ou } \\
\text { identidade pessoal }\end{array}$ & $\begin{array}{l}\text { As imagens postadas são } \\
\text { consideradas "irreais", } \\
\text { ilusórias, não verdadeiras } \\
\text { ou limitadas quanto à } \\
\text { representatividade do eu. }\end{array}$ & $\begin{array}{l}\text { "Acho que uma sim- } \\
\text { ples imagem não é } \\
\text { capaz de contar uma } \\
\text { história a todos que } \\
\text { veem, acredito que } \\
\text { só realmente aqueles } \\
\text { que me conhecem." }\end{array}$ \\
& $\begin{array}{l}\text { "Nenhuma imagem } \\
\text { postada no meu } \\
\text { Facebook represen- } \\
\text { ta completamente } \\
\text { minha identidade, } \\
\text { até porque acredito } \\
\text { ser a identidade algo } \\
\text { fluido, que vai se } \\
\text { construindo ao longo } \\
\text { das experiências que } \\
\text { vou tendo." }\end{array}$ \\
\hline
\end{tabular}

Fonte: elaborada por Idilva Maria Pires Germano.

\subsection{Razões para partilhar a imagem}

As 42 respostas à questão 4 foram distribuídas em 11 categorias de razões/ motivos para partilhar a imagem na rede: "porque expressa sua beleza física (14, 28\%)"; "quis partilhar e estimular nos outros estado de espírito" (19,04\%); "porque expressa quem é" (7,14\%); "para recordar momentos" (2,38\%); "porque expressa a qualidade estética da imagem" (14,28\%); "porque queria divulgar atividade e eventos (incluindo autopromoção)" (7,14\%); "para atualizar fotos no Facebook" (7,14\%); "para exibir lugares e momentos para pessoas ausentes" (19,04\%); "para mostrar sua família aos amigos" (2,38\%).

Entre as razões para o compartilhamento da imagem, destaca-se a predominância de motivos associados à conectividade e manutenção de futuras interações. Nessas razões, observa-se a necessidade da "presença" de outro sujeito para dar sentido à publicação. A interatividade na construção e manutenção identitária pode ser acompanhada nos argumentos para a partilha de imagens, que tem sempre como norte a possível reação dos amigos ou seguidores na rede. Os argumentos são baseados na expressão de estados de espírito, apresentação de lugares frequentados, familiares e do próprio corpo, todos marcados, pelos próprios entrevistados, como elementos que possibilitam o conhecimento, embora parcial, dos retratados. Mas como lembram Zhao et al. (2008), as identidades on-line aproximam-se de identidades possíveis ou desejadas, nem sempre consistentes com a "vida real" e muito dependentes de comentários positivos 
que descrevem o indivíduo como socialmente desejável e extrovertido. É evidente entre nossos entrevistados a expectativa de um feedback do público, que os incita à partilha de mais e mais imagens de si. Os dados coletados tendem a corroborar hipóteses que afirmam que a customização de perfis forneceria evidências da identidade reivindicada, aguardando a necessária aprovação do público (Rosa \& Santos, 2013). O participante 28 afirma: "Gostaria que todos vissem esse bom momento e, se possível, comentassem também, pois a opinião dos amigos é importante, influencia muito no modo em que vejo as coisas".

Outro ponto a ser destacado é a frequência $(28,56 \%)$ de razóes envolvendo beleza física e efeitos visuais, considerados pelos entrevistados como elementos que estilizam a imagem como um todo, tornando-a artística.

Em geral, apreende-se que a customização dos perfis tende a envolver a escolha de imagens que prezem pela construção de uma identidade visual e socialmente modulada e pela clara necessidade de um feedback do público. Contudo um ponto para mais investigação é o aspecto estratégico da escolha de imagens, que, embora numerosas e frequentemente atualizadas, não explicitam "quem é" o usuário, mas sim traços ou pistas dessa identidade, que operam mantendo o público em um estado constante de desejo por um desvelamento total do self em meio ao panorama de "clicks" que compõem o perfil (Hum et al., 2011).

\subsection{Percepção da reação dos amigos à imagem}

As 33 respostas à questão 5 foram distribuídas em 5 categorias de reação dos amigos à imagem postada no Facebook: "alta aprovação" (57,57\%), "aprovação regular" (24,24\%), "amigos não viram" (3,03\%), "não tenho certeza" (9,09\%), "não respondeu" (6,06\%). Os participantes tendem a perceber que as imagens postadas foram bem recebidas entre seus contatos, com mais de $80 \%$ de respostas de "aprovação". As redes sociais são ambientes de observação e monitoramento constante das interações e atividades que ocorrem nesses espaços virtuais. Como afirmam Karakayali e Kilic (2013), os usuários das redes "desenvolvem a tendência a se tornarem altamente observadores e inquisitivos sobre suas redes" e frequentemente se envolvem numa atividade que denominam de "trabalho analítico" (p. 175). O termo abrange não somente a observação regular e categorização de outros usuários na rede social, mas também a avaliação e interpretação do comportamento on-line dos demais. Os usuários empenham-se na reflexão de seus laços sociais mediante observação de seus contatos na rede e, por outro lado, também estão cientes de que são regularmente observados.

Rosa e Santos (2013) apontam que as fotos postadas no Facebook são elementos de grande importância na dinâmica interacional, pois, além de sua 
função na customização ou personalização dos perfis, também são geradoras de uma audiência que legitima as reivindicaçôes identitárias dos retratados, por meio de recursos oferecidos pela plataforma do Facebook, especialmente as opçôes "curtir" e "escreva um comentário".

É bom saber, nem que seja pelo número de curtidas, o quanto isso impactou, e melhor ainda é poder ler as reações e opiniōes que as pessoas postam nos comentários. Sempre fica um pouco de expectativa para saber qual o impacto que isso vai gerar (Participante 18).

"Se ninguém tivesse curtido, eu iria pensar duas vezes antes de compartilhar [...] Acho que a reação das pessoas ao que posto nas redes sociais me move" (Participante 20).

A maioria das respostas obtidas aponta que se busca o consentimento e a aprovação dos demais usuários da rede e, por essa razão, o gerenciamento dos perfis do Facebook não é uma atividade realizada de modo displicente. Rosa e Santos (2013) afirmam que, não pretendendo ser malvistos no site, "os usuários procuram representar-se seguindo padrões de estética e de sentimentos considerados interessantes" (p. 105).

\subsection{Estímulo para produzir novas imagens de si similares}

As 33 respostas à questão 6 ("As respostas de seus amigos no Facebook a essa imagem lhe estimularam a produzir e partilhar novas imagens parecidas com essa?") foram distribuídas nas seguintes categorias: "sim, certamente" (54,54\%); "não" $(30,30 \%)$; "frequentemente" (3,03\%); "em termos/posto imagens diferentes" (3,03\%); não respondeu/não sei/outras $(9,09 \%)$. Os resultados expressivos na categoria "sim, certamente" (54,54\%) encontram ressonância noutros estudos que examinam interações em ambientes on-line de compartilhamento de fotografias; por exemplo, Ribeiro e Braga (2012). A construção de referenciais identitários é uma prática performática, que ocorre num jogo entre o feedback dos amigos da rede social (visualizado nos comentários e "curtidas") e as expectativas criadas sobre esses (Ribeiro \& Braga, 2012, p. 80). A aprovação, por parte dos amigos e seguidores, de uma imagem publicada estimula a maior parte dos respondentes a produzir novas publicações semelhantes. Com base nesse dado, consideramos que a legitimação por parte do olhar do outro engendra no Facebook uma complexa rede de sociabilidade entre os usuários da rede, o que incita e mantém uma atividade social a ele peculiar.

Opondo-se a uma maioria que admite a importância da aprovação de seus contatos, para a produção de novas publicações, menos de um terço dos 
participantes negou a influência dos amigos para o compartilhamento de novas imagens: "Nada da reação dos meus amigos me estimula a continuar postando fotos do mesmo estilo" (Participante 13) e "Não, porque não utilizo o referencial alheio para escolher as fotos que partilho" (Participante 23). Essas e outras respostas podem assinalar uma atitude contrária à exibição narcísica do eu, que receia a superexposição da vida privada e rejeita o excesso de visibilidade nas redes sociais. Outras respostas revelam esse olhar crítico: "Não vou a um lugar e posto fotos disso, é muita exposição" (Participante 31) e "Não, pra ser sincera, acho bem bobo e pouco interessante ficar postando foto de tudo que acontece consigo aqui, em busca de popularidade, ou seja lá o quê. Acho que é um nível de vaidade que eu não tenho e não quero ter" (Participante 15).

\section{CONSIDERAÇÕES FINAIS}

Este estudo exploratório discute a representação do eu em sites de redes sociais, questionando em que medida é moldada pelas novas "tecnologias do olhar" (tais como câmeras digitais, celulares, tablets, plataformas digitais) que multiplicam a produção e consumo de imagens na vida contemporânea. Em especial, buscou discutir a percepção que usuários do Facebook têm acerca de imagens pessoais que partilham nessa rede social.

Os resultados do estudo tendem a corroborar os achados de pesquisas recentes que sublinham o crescente papel que as imagens de si desempenham na representação do eu on-line, decorrente da acessibilidade dos equipamentos digitais e da expansão da internet. Entre os achados, destacam-se as imagens e argumentos associados à diversão, felicidade e autenticidade, que apoiam análises anteriores realçando a dominância de alguns valores disseminados na sociedade de consumo, bem como as práticas de comunicação e de apresentação de si. Os participantes empenham-se em construir identidades "possíveis e esperadas", nem inteiramente falsas (uma vez que o Facebook não é uma rede anônima, portanto, as informações podem ser confrontadas com a "realidade") nem inteiramente correspondentes às identidades construídas off-line (uma vez que, no Facebook, é possível barganhar identidades "melhoradas", idealizadas e socialmente mais desejáveis, evitando transmitir à audiência informações indesejáveis à manutenção da imagem positiva).

Os resultados sugerem que fotografias digitais estão entre as principais ferramentas para a representação do eu e administração de laços sociais entre jovens na faixa etária estudada. Estar no Facebook envolve um cuidadoso esforço de monitoramento da própria atividade de escolher, divulgar as imagens pessoais e observar a recepção de suas publicações nesse espaço, bem como da atividade semelhante de seus contatos na rede. As imagens são utilizadas, principalmente, para transmitir uma imagem de si desejável (feliz, sociável, bonito ou bonita) e 
também para avaliar e categorizar estilos de vida, gostos e preferências de outros usuários. Essa imagem não é considerada exatamente falsa ou manipulada, mas representa com certa fidelidade certas qualidades, modo ou estilo de vida predominante do usuário. Este está ciente de que as imagens podem de fato ser mentirosas e ameaçar a reivindicação de autenticidade do retratado (afinal, imagens podem ser editadas e induzir a inferências equivocadas). Daí, não parecer falso para seus contatos é um valor que orienta a escolha e a partilha de imagens, o que não impede certo "melhoramento" da imagem de si e a expectativa da aprovação alheia do conteúdo partilhado.

Ponto importante é que o usuário entende que as imagens não dão acesso à sua história de vida ou autobiografia. A produção massiva de imagens hoje ressalta a função tática e performática da fotografia (para a publicidade e para a garantia das interaçôes) e menos seu papel na construção narrativa da história pessoal. Muitas dessas imagens postadas nas redes, uma vez atualizadas, não serão mais revisitadas pelo usuário nem por seus contatos. Embora no Facebook se pratique uma atividade que pode ser inclusa no gênero autobiográfico (uma vez que, para a audiência, mantém-se uma equivalência entre o autor da página, o "narrador" que posta imagens e comentários e o personagem principal), parece haver lá uma perda da articulação temporal e autorreflexão consciente das experiências necessárias para que o usuário compreenda aquele espaço como lugar de construção ou trabalho autobiográfico. Parece que uma rede como o Facebook, destinada a uma navegação rápida, interativa, dispersa e centrada na partilha de imagens carece da "potência aurática" (Sibilia, 2008, p. 37) associada às formas confessionais de experiências íntimas do passado.

No âmbito das limitações do estudo, o fato de ter privilegiado a percepção consciente do ator social sobre a produção e distribuição de suas imagens pessoais on-line pode levantar questóes sobre as estruturas e processos culturais não conscientes que animam as atividades dos usuários de redes sociais. Essas questóes podem ser mais bem respondidas por outros delineamentos que endereçam claramente essa estruturação, podendo, por exemplo, esclarecer os novos habitus do produtor das imagens e do próprio retratado em tais espaços. Pesquisas nesse sentido podem se voltar para uma análise iconográfica das imagens e menos para os textos que acompanham as imagens. Também hipóteses mais dirigidas podem ser refinadas sobre os efeitos da produção e troca excessiva de imagens na rede sobre a memória, a narrativa e a experiência de si em redes sociais, considerando diferenças culturais e especificidades populacionais, especialmente idade e sexo dos usuários.

Por fim, concluímos que, numa cultura dominantemente visual e espetacularizada, as tecnologias do olhar tem desempenhado papel decisivo na construção das identidades e nas práticas autobiográficas on-line "alterdirigidas". 


\section{REFERENCIAS}

Banks, A. (2014, 22 maio). Brazil digital future in focus 2014. [S.1.]: ComScore. Recuperado a partir de http://www.comscore.com/por/Insights/Presentationsand-Whitepapers/2014/2014-Brazil-Digital-Future-in-Focus-Webinar

Carrera, F. (2014). O imperativo de felicidade em redes de sites sociais: materialidade como subsídio para o gerenciamento de impressões (quase) sempre positivas. Revista Eptic Online, 16(1), 33-44.

Chou, H. G. \& Edge, N. (2012). "They are happier and having better lives than I am": the impact of using Facebook on the perceptions of others' lives. Cyberpsychology, behavior and social networking, 15(2), 117-121.

Dijck, J. (2008). Digital photography: communication, identity, memory. Visual Communication, 7(1), 57-76.

Dijck, J. (2013). "You have one identity": performing oneself on Facebook in Linkedln. Media, Culture \& Society, 35(2), 199-215.

Goffman, E. (2009). A representação do eu na vida cotidiana. M. C. S. Raposo, (Trad.) Petrópolis: Vozes.

Goodings, L. (2012). Understanding social network sites: lessons from MySpace. Visual Communication, 11(4), 485-509.

House, N. A. (2009). Collocated photo sharing, story-telling and the performance of self. International Journal of Human-Computer Studies, 67(12), 1073-1086.

Hum, N. J., Chamberlin, P. E., Hambright, B. L., Portwood, A. C., Schat, A. C. \& Bevan, J. L. (2011). A picture is worth a thousand words: a content analysis of Facebook profile photographs. Computers in Human Behavior, 27(5), 18281833.

Karakayali, N. \& Kilic, A. (2013). More network conscious than ever? Challenges, strategies, and analytic labor of users in the Facebook environment. Journal of Computer-Mediated Communication, 18(2), 175-193.

Livingstone, S. (2012). Tomando oportunidades arriscadas na criação de conteúdo jovem: o uso pelos adolescentes de sites de redes sociais para intimidade, privacidade e expressão própria. Comunicação, mídia e consumo, 9(25), 91-118. 
Nosko, A., Wood, E. \& Molema, S. (2010). All about me: disclosure in online social networking profiles: the case of Facebook. Computers in Human Behavior, 26, 406-418.

Oliveira, F. (2018, 18 julho). Facebook chega a 127 milhões de usuários mensais no Brasil. Folha de São Paulo. Recuperado a partir de https://www1.folha.uol. com.br/tec/2018/07/facebook-chega-a-127-milhoes-de-usuarios-mensais-nobrasil.shtml

Pina, H. F. (2005). O corpo como tela. Lisboa: Escola Superior de Comunicação Social (Instituto Politécnico deLisboa). Recuperado apartirdehttp://repositorio. ipl.pt/bitstream/10400.21/841/1/Comunica \%C3\%A7\%C3\%A3o\%20 CORPO\%20COMO\%20TELA\%20-\%20Actas\%204SOPCOM-1.pdf

Ribeiro, J. C. \& Braga, V. (2012). Interações em ambientes online de compartilhamento de fotografias: considerações baseadas nas perspectivas interacionista e dramatúrgica. Revista Famecos: Midia, Cultura e Tecnologia, 19 (1), 65-82.

Roberts, B. (2011). Interpreting photographic portraits: autobiography, time perspectives and two school photographs. Forum Qualitative Sozialforschung/ Forum: Qualitative Social Research, 12(2), art. 25. Recuperado a partir de http://nbn-resolving.de/urn:nbn:de:0114-fqs1102252

Rosa, G. A. M. \& Santos, B. R. (2013). Facebook e as nossas identidades virtuais. Brasília: Thesaurus.

Rosemberg, J. \& Egbert, N. (2011). Online impression management: personality traits and concerns for secondary goals as predictors of self-presentation tactics on Facebook. Journal of Computer-Mediated Communication, 17, 1-18.

Schafie, L. A., Nayan, S. \& Osman, N. (2012). Constructing identity through Facebook profiles: on-line identity and visual impression management of university students in Malaysia. Procedia: Social and Behavioral Sciences, 65, 134-140.

Sibilia, P. (2008). O show do eu: a intimidade como espetáculo. Rio de Janeiro: Nova Fronteira.

Stutzman, F., Vitak, J., Ellison, N., Gray, R. \& Lampe, C. (2012). Privacy in interaction: exploring disclosure and social capital in Facebook. In Proceedings of the 6th annual International Conference on Weblogs and Social Media. Washington: Association for the Advancement of Artificial 
Intelligence. Recuperado a partir de http://wwwpersonal.umich.edu/ -enicole/ StutzmanVitakEllisonGrayLampe2012_ICWSM.pdf

Wilson, R. E., Gosling, S. \& Graham, L.T. (2012). A review of Facebook research in the Social Sciences. Perspectives on Psychological Science, 7(3), 203-220.

Zhao, S., Grasmuck, S. \& Martin, J. (2008). Identity construction on Facebook: digital empowerment in anchored relationships. Computer in Human Behavior, 24 (5), 1816-1836. 